\title{
Impact of variety type and particle size distribution on starch enzymatic hydrolysis and functional properties of tef flours
}

3

4

5

6

Workineh Abebe $^{\mathrm{ab}}$, Concha Collar ${ }^{\mathrm{c}}$, Felicidad Ronda ${ }^{\mathrm{a}^{*}}$

${ }^{\text {a }}$ College of Agricultural and Forestry Engineering. University of Valladolid.

7 Av. Madrid 57, 34004, Palencia, Spain.

8

${ }^{\mathrm{b}}$ Ethiopian Institute of Agricultural Research. P.O.Box 2003, Addis Ababa, Ethiopia.

${ }^{c}$ Food Science Department, Instituto de Agroquímica y Tecnología de Alimentos

11

(CSIC), Avenida Catedrático Agustín Escardino 7, Paterna 46980, Valencia, Spain.

12

*Corresponding author: Tel: 34979108339; Fax: 34979 108302; E-mail address: 
Tef grain is becoming very attractive in the Western countries since it is a gluten-free grain with appreciated nutritional advantages. However there is little information of its functional properties and starch digestibility and how they are affected by variety type and particle size distribution. This work evaluates the effect of the grain variety and the mill used on tef flour physico-chemical and functional properties, mainly derived from starch behaviour. In vitro starch digestibility of the flours by Englyst method was assessed. Two types of mills were used to obtain whole flours of different granulation. Rice and wheat flours were analyzed as references. Protein molecular weight distribution and flour structure by SEM were also analyzed to justify some of the differences found among the cereals studied. Tef cultivar and mill type exhibited important effect on granulation, bulking density and starch damage, affecting the processing performance of the flours and determining the hydration and pasting properties. The colour was darker although one of the white varieties had a lightness near the reference flours. Different granulation of tef flour induced different in vitro starch digestibility. The disc attrition mill led to higher starch digestibility rate index and rapidly available glucose, probably as consequence of a higher damaged starch content. The results confirm the adequacy of tef flour as ingredient in the formulation of new cereal based foods and the importance of the variety and the mill on its functional properties.

40 Keywords: tef; in vitro starch digestibility; milling; functional properties 


\section{Introduction}

42 Tef [Eragrostis tef (Zucc.)Trotter] grain, originated from Ethiopia, is becoming a very attractive cereal in the Western world since it is a gluten-free grain encompassing highly appreciated nutritional advantages. Tef grain size is known to be extremely small with mean length ranging $0.61-1.17 \mathrm{~mm}$ and mean width ranging $0.13-0.59 \mathrm{~mm}$, that gives an average thousand kernel weight of $0.264 \mathrm{~g}$ (Bultosa, 2007). Tef grain anatomy studies by Parker et al. (1989) and Umeta and Parker (1996) indicate that the embryo, rich in protein and lipid, occupies a relatively large part of the grain. The aleurone layer is one cell thick and rich in protein lipid bodies. The testa is located within the pericarp and its thickness varies with the color of the grain. The testa of red tef is thicker than compounds (Umeta and Parker, 1996). Tef grain is consumed as a whole meal and has more iron, calcium and zinc than other cereal grains, including wheat, barley and sorghum (Abebe, Bogale, Hambidge, Stoecker, Bailey \& Gibson, 2007). The grain proteins offer an excellent balance among the essential amino acids (Yu, Sun, Rota, Edwards, Hailu, \& Sorrells, 2006). Tef has recently been receiving global attention as a "healthy food", suitable for its employment in novel foods such as baby foods and gluten-free based goods (Dekking, Winkelaar, \& Koning, 2005).

Different milling or grinding processes have been shown to produce different flours with different particle size and degree of damage of starch granules in flour, depending on the mechanical forces and temperature during the grinding process (Kadan, 2008). The kinetics of starch digestion by alpha amylase of barley and sorghum flours were found to be dependent on the particle size of flours (Al-Rabadi Gilbert, \& Gidley, 2009). Starch damage encompasses disruption of the granular structure (Level 5) of the 
the starch size, botanical source and milling condition (Li, Dhital, \& Hasjim, 2014). The extent of starch damage is known to affect the quality and functionality of the flours. In Ethiopia tef is mainly processed to injera after milling with disc attrition mills available in cottage grain mill houses. Injera with much and evenly spread eyes, soft texture, easily rollable and bland after taste is rated as excellent. Intrinsic tef flour quality factors which favor these quality aspects include starch granule characteristics and the higher water solubility index of tef flour which positively influence injera quality (Yetneberk, Rooney, \& Taylor, 2005).

The effect of milling method on starch damage, flour physical and functional properties and end product quality for common cereals like wheat and rice is well known (Kadan, Bryant, \& Miller, 2008; Al-Rabadi et al., 2009; Tran et al., 2011). However, despite the nutritional interest and peculiarities of tef grain, information available on the functional properties and starch digestibility and its dependence on grain variety and granulation are still lacking. Therefore, the objective of this research was to identify the influence of two types of mills on the physical and functional properties and the starch digestibility of flours from three Ethiopian tef varieties, to properly assess the end use of tef flours thereof. Protein molecular weight distribution and flour structure by SEM were also evaluated to establish their significance on functional properties.

\section{Materials and methods}

\subsection{Material}

Three tef varieties DZ-01-99 (brown tef), DZ-Cr-37 (white tef) and DZ-Cr-387

87 (Qouncho, white tef) were obtained from the Debre Zeit Agricultural Research Center 88 of the Ethiopian Institute of Agricultural Research (EIAR). Rice flour, whole wheat and 89 refined wheat flours used as references were supplied by Emilio Esteban SA 
(Valladolid, Spain). The proximal composition of the flours from the tef grains and the reference flours are shown in Table 1. Moisture, ash, fat and protein contents of the flours were determined using methods 44-19, 08-01, 30-25 and 46-11A of AACC (AACC, 2000) respectively. Total carbohydrates were determined by difference to $100 \%$ (FAO, 2003). Starch content was determined by Fraser, Brendon-Bravo \& Holmes (1956) method and amylose and amylopectin with the Megazyme assay kit (Megazyme Bray, Ireland). All the assays were conducted in duplicate.

\subsection{Milling process}

The tef grains were manually cleaned by sifting and winnowing before milling. Two types of mills were used to obtain the whole flour of the three tef varieties. The first one was Cyclotech Sample mill (Foss Tecator, Häganäs Sweden) fitted with a $0.5 \mathrm{~mm}$ opening screen size (Mill 1). The second mill was a disc attrition mill (Mill 2) which is the type traditionally used in cottage tef grain-milling house (Bishoftu, Ethiopia) to mill tef grain for injera making in Ethiopia. The moisture content levels of the three tef cultivar grains were equivalent $(10.3-10.5 \%, \mathrm{p}>0.05)$ and in a normal range for field dried tef grains (Bultosa, 2007).

\subsection{Protein characterization}

All gels were run in minislabs (Bio-Rad Mini Protean II Model). Sodium dodecyl sulphate (SDS)-PAGE was performed according to Laemmli's method (1970) using continuous gels $(12 \%)$. Flour samples $(1 \%$, w/v) were dissolved in $0.125 \mathrm{M}$ Tris-HCl, pH 6.8 buffer containing $0.02 \%(\mathrm{v} / \mathrm{v})$ glycerol, $0.1 \%(\mathrm{w} / \mathrm{v})$ SDS and $0.05 \%(\mathrm{w} / \mathrm{v})$ bromophenol blue, and centrifuged at $15800 \mathrm{x}$ g for $5 \mathrm{~min}$ at $4^{\circ} \mathrm{C}$. Supernatants were loaded onto the gel (30-40 $\mu \mathrm{g}$ of protein per lane). Samples to be run under reducing conditions were boiled for $1 \mathrm{~min}$ in $0.005 \%(\mathrm{v} / \mathrm{v}) 2$-mercaptoethanol (2-ME) buffer before centrifugation. Electrophoresis was conducted for $1 \mathrm{~h}$ at a constant voltage of 
$200 \mathrm{~V}$. The following molecular weight standards were used to estimate the molecular masses of polypeptides: phosphorylase b (94 kDa); bovine serum albumin $(67 \mathrm{kDa})$; ovalbumin $(45 \mathrm{kDa})$; carbonic anhydrase $(30 \mathrm{kDa})$; trypsin inhibitor $(20.1 \mathrm{kDa})$; $\alpha$ lactalbumin (14.4 kDa), (Pharmacia Hepar Inc, Franklin, OH, U.S.A).

\subsection{Granulation and density of flours}

Flour particle size distribution was measured using a Sympatec Particle size and shape analyser (Sympatec GmbH, Germany) using diffraction of laser light and controlled by HELOS particle size analysis Window 5 software. The particle size distribution was characterized by the mean diameter $\left(\mathrm{D}_{50}\right)$ and the dispersion $\left(\left(\mathrm{D}_{90}-\mathrm{D}_{10}\right) / \mathrm{D}_{50}\right)$ as described in Landillon, Cassan, Morel \& Cuq (2008). Bulk density (BD) of the flours was determined according to Kaushal et al. (2012). Flour samples were gently poured into previously tared $10 \mathrm{ml}$ graduated cylinders. The final volume reading was taken after vibrating the sample until constant value. Flour true density (TD) was determined by liquid displacement method with toluene as described in Deshpande \& Poshadri (2011) by using 50ml pycnometers for the determination.

\subsection{Flour Color}

A Minolta spectrophotometer CN-508i (Minolta, Co.LTD, Japan) was used for flour color measurements. Results were obtained in the CIE L*a*b coordinates using the D65 standard illuminant, and the $2^{\circ}$ standard observer. The hue $(\mathrm{h})$ and the chroma $\left(\mathrm{C}^{*}\right)$ were calculated from the equations 1 and 2 respectively. The spectrophotometer was programmed to report an average of 5 measurements.

$h=\tan ^{-1}\left(\frac{b^{*}}{a^{*}}\right)$

$$
C^{*}=\left((a *)^{2}+(b)^{2}\right)^{1 / 2}
$$


139 The damaged starch content in flour samples was determined in accordance with the

140 American Association of Cereal Chemists (AACC) method (AACC, 2012), by using

141 Megazyme starch damage kit (Megazyme International Ireland Ltd, Co. Wicklow,

142 Ireland). Absorbance was read at $510 \mathrm{~nm}$ in a microplate reader BIOTEK EPOCH

143 (Izasa, Barcelona, Spain). The damaged starch was determined as percentage of flour

144 weight on a dry basis. Three replicates were made for each sample.

\subsection{Technological functional properties}

146 Foaming capacity (FC) and foam stability (FS) were determined as described by Collar

147 \& Angioloni (2014a, b) based on the methods used by Alu'datt, Rababah, Ereifej, Alli, 148 Alrababah, Almajwal, Masadeh, \& Alhamad (2012). Briefly, $2 \mathrm{~g}$ of flour sample was 149 mixed with $40 \mathrm{ml}$ distilled water at $30^{\circ} \mathrm{C}$ in a $100 \mathrm{ml}$ measuring cylinder. The 150 suspension was stirred and shaken manually for $5 \mathrm{~min}$ to produce foam. The volume of foam was measured after 0 min (VT) and $60 \mathrm{~min}$ (V1). FC was calculated directly from VT while FS was calculated from $100 *(\mathrm{~V} 1 / \mathrm{VT})$.

The water holding capacity (WHC), the amount of water retained by the sample without being subjected to any stress, was determined with slight modification of the method used by Nelson (2001). Samples $(2.000 \mathrm{~g} \pm 0.005 \mathrm{~g})$ were mixed with distilled water $(20$ $\mathrm{ml}$ ) and kept at room temperature for $24 \mathrm{~h}$. The supernatant was removed and WHC was measured as grams of water retained per gram of solid. The swelling volume (SV) was obtained by dividing the total volume of the swollen sample by the original dry weight of the sample (Nelson, 2001).

Water absorption capacity (WAC) and oil absorption capacity (OAC) of the flours were determined by the centrifugation method described by Beuchat (1977). Two grams of 
162 flour were mixed with $20 \mathrm{~mL}$ of distilled water or corn oil in $50 \mathrm{~mL}$ centrifuge tubes.

163 The dispersions were occasionally vortexed while they were held at room temperature 164 for $30 \mathrm{~min}$, followed by centrifugation for $30 \mathrm{~min}$ at $3000 \mathrm{x} g$ (Orto Alresa, Spain). The 165 supernatant was removed and weighed and results were expressed as grams of water or 166 oil retained per gram of flour.

167 Water absorption index (WAI) and water solubility index (WSI) of the flours were measured as described in Kaushal, Kumar \& Sharma (2012). $2.5 \mathrm{~g}$ of flour sample ( $\left.\mathrm{w}_{0}\right)$ was dispersed in $30 \mathrm{ml}$ of distilled water, using a glass rod, in tared centrifuge tubes; then cooked at $90^{\circ} \mathrm{C}$ for $10 \mathrm{~min}$, cooled to room temperature and centrifuged at $3000 \mathrm{x} \mathrm{g}$

171 for $10 \mathrm{~min}$. The supernatant was poured into a pre-weighed evaporating dish to 172 determine its solid content and the sediment was weighed $\left(\mathrm{w}_{\mathrm{ss}}\right)$. The weight of dry 173 solids was recovered by evaporating the supernatant overnight at $110^{\circ} \mathrm{C}\left(\mathrm{w}_{\mathrm{ds}}\right)$. WAI, 174 WSI and swelling power (SP) were calculated from the equations:

$175 \quad \mathrm{WAI}(\mathrm{g} / \mathrm{g})=\frac{\mathrm{w}_{\mathrm{ss}}}{\mathrm{w}_{0}}$

$176 \quad$ WSI $(\mathrm{g} / 100 \mathrm{~g})=\frac{\mathrm{W}_{\mathrm{ds}}}{\mathrm{w}_{0}} \times 100$

$177 \quad \mathrm{SP}(\mathrm{g} / \mathrm{g})=\frac{\mathrm{w}_{\mathrm{ss}}}{\mathrm{w}_{0}-\mathrm{w}_{\mathrm{ds}}}$

\subsection{Pasting properties of flours}

179 Pasting properties were studied by using Rapid Visco Analyzer (RVA-4, Newport Scientific Pvt. Ltd, Australia) using ICC standard method 162. Parameters recorded were pasting temperature (PT), peak viscosity (PV), trough viscosity (TV), final viscosity $(\mathrm{FV})$, breakdown viscosity $(\mathrm{BV})$, setback viscosity (SV), and peak time (Pt). 
RVA parameters were calculated from the pasting curve using Thermocline v. 2.2 software. Analysis was done in triplicate.

\subsection{Scanning electron microscopy (SEM)}

186

187

A Scanning Electron Microscope (SEM) model Quanta 200-F (FEI, Oregon, USA) was used to examine the flours. This microscope was equipped with an X-ray detector and allowed the analysis of samples of low conductivity without prior metallization. The samples were directly mounted on stubs. Observations were made with an accelerating voltage of $1.5 \mathrm{keV}$.

\subsection{Starch fractions analysis}

In vitro starch digestibility was measured according to Englyst, Kingman, \& Cummings (1992), including the latest modifications (Englyst, K., Englyst, H., Hudson, Cole, \& Cummings,1999; Englyst, K., Hudson, \& Englyst, H., 2000) as previously applied Ronda, Rivero, Caballero, \& Quilez (2012). The hydrolysed glucose at $20 \min \left(\mathrm{G}_{20}\right)$ and $120 \min \left(\mathrm{G}_{120}\right)$ and the total glucose (TG) were determined by glucose oxidase colorimetric method and with six repetitions for each. The free sugar glucose (FGS) content was also determined through a separate test following the procedure proposed by Englyst et al. (2000). From the above results, rapidly digested starch (RDS) = $0.9 *\left(\mathrm{G}_{20}-\mathrm{FGS}\right)$, slowly digestible starch $(\mathrm{SDS})=0.9 *\left(\mathrm{G}_{120}-\mathrm{G}_{20}\right)$, resistant starch $(\mathrm{RS})$ $=0.9 *\left(\mathrm{TG}-\mathrm{G}_{120}\right)$, total starch $(\mathrm{TS})=0.9 *(\mathrm{TG}-\mathrm{FGS})$ and rapidly available starch $(\mathrm{RAG})=\mathrm{G}_{20}$ were calculated. Starch digestibility rate index (SDRI) was computed from the percentage of RDS in TS in the flours.

\subsection{Statistical analysis}

Experimental data were analyzed using two-way analysis of variance (MANOVA) and then means were then compared at $\mathrm{p}<0.05$ using Fisher's least significant difference 
207 (LSD) test. Statistical analysis was done by Statgraphics Centurion XVI program

208 (StatPoint Technologies, Inc. 1982-2010).

209

210

211

212

213

214

215

216

217

218

219

220

221

222

223

224

225

226

227

228

\section{RESULTS AND DISCUSSION}

\subsection{Protein Characterization}

The three tef cultivars showed similar protein profiles which were different from the reference flours (Figure 1). Under non-reducing conditions, polypeptides of 67-65, 56, $52,35,28,25$ and $<20 \mathrm{kDa}$ were observed in the three tef flours. The polypeptide of 52 $\mathrm{kDa}$ (Figure 1a, arrow 1) was dissociated by 2-ME reducing agent in tef flours while an increase in the intensity of bands between 20 and $30 \mathrm{kDa}$ was observed under reducing conditions (Figure 1b), denoting the presence of disulfide bridges. Rice showed similar protein profile to tef under non-reducing conditions except two new polypeptides at 32 $\mathrm{kDa}$ (arrow 2) and $20 \mathrm{kDa}$ (arrow 3). Under reducing conditions the $32 \mathrm{kDa}$ band increased in intensity and a new polypeptide of $25 \mathrm{kDa}$ appeared. As for most other cereals, prolamins are major storage proteins in tef (Adebowale, Emmambux, Beukes, \& Taylor, 2011). However, protein fractions in tef are less complex than those of wheat, in terms of their apparent molecular size differences, and resemble more the pattern found in maize (Shewry \& Tatham, 1990; Hager, Wolter, Jacob, Zannini, \& Arendt, 2012).

\subsection{Granulation and density of flours}

Granulation and uniformity of particle size have long been assumed to be important factors affecting the processing performance of flours. The mean diameters of flour particles $\left(\mathrm{D}_{50}\right)$ of tef flours varied significantly (Table 2) in the order DZ-01-99 (92.4 $\mu \mathrm{m})<$ DZ-Cr-387 $(94.9 \mu \mathrm{m})<$ DZ-Cr-37 $(96.6 \mu \mathrm{m})$, noting also significantly higher values for mill $1(96.2 \mu \mathrm{m})$ than mill $2(93.3 \mu \mathrm{m})$. The $\mathrm{D}_{50}$ of the tef flours was higher than in wheat flour $(56.8 \mu \mathrm{m})$ and lower than in rice flour $(142.4 \mu \mathrm{m})$. However, earlier 
232 work on three common wheat flours showed $\mathrm{D}_{50}$ values ranging from 64 to $99 \mu \mathrm{m}$

233 (Landillon et al., 2008) indicating the high dependence of wheat flour particle size on

234 variety type. The size dispersion of tef cultivar flours $(2.32-2.36)$ was notably higher

235 than those of wheat and rice flours. This difference could be attributed to continuous

236 sieving processes during industrial milling of the reference flours. Mill 2 led to

237 significantly lower size dispersion (2.13) than mill $1(2.55)$ which shows that the discs

238 mill gave flour of more uniform size. For the three tef cultivars mill 1 generated flours

239 with bimodal particle size distribution $(4.5-150 \mu \mathrm{m}$ and 150-850 $\mu \mathrm{m})$. In both, $\mathrm{D}_{50}$ and

240 size dispersion, significant $(\mathrm{p}<0,01)$ variety $\mathrm{x}$ mill interaction was observed. The less

241 pronounced effect of mill type on $\mathrm{D}_{50}$ was observed in the DZ-Cr-387 variety while the

242 most impact on the size dispersion was detected for DZ-01-99.

243 The bulk densities (BD) and true densities (TD) of the tef cultivar flours showed significant $(p<0.01)$ variations depending on the variety and the mill. DZ-01-99 flour obtained from the mill 2 had the lowest values (Table 2). BD can be used to predict packaging requirements of the flours (Akubor, 2007). Tef flours from mill 1 had significantly $(\mathrm{p}<0.01)$ higher mean $\mathrm{BD}\left(0.86 \mathrm{~g} / \mathrm{cm}^{3}\right)$ than those from mill $2\left(0.80 \mathrm{~g} / \mathrm{cm}^{3}\right)$ and the mill type influence being more visible on DZ-Cr-387 than on the other tef cultivars. This could be due to the fact that mill 1 led to flours with higher average particle size than mill 2 and agrees with the statement of Brown \& Richards (1970) describing powders with a fine structure pack loosely than aggregated granules and samples of larger particle size will give higher densities. As it could be expected, the type of mill did not affect TD as it is mainly dependent on flour composition but not on particle size.

\subsection{Flour color}


256 The average lightness $\left(\mathrm{L}^{*}\right)$ of grain flours from the three tef varieties varied markedly $257(\mathrm{p}<0.01)$ in the order DZ-01-99 (67.4) < DZ-Cr-37 (78.0) $<$ DZ-Cr-387(82.4) (Table 2).

258 The hue angle (h) of the tef flours also varied from reddish to the yellowish in the order: DZ-01-99< DZ-Cr-37<DZ-Cr-387. However, compared with wheat and rice flours they all showed lower $\mathrm{L}^{*}$ and $\mathrm{h}$. A similar trend of $\mathrm{L}^{*}$ and $\mathrm{h}$ was recorded on the gels from the three tef cultivars (Abebe \& Ronda, 2014). DZ-01-99 grain flour exhibited the darkest and most red flour that could be due to tannin or polyphenol compounds (Umeta \& Parker, 1996). The average chroma (C*) of DZ-Cr-387 (15.2) and DZ-Cr-37 (15.2) grain flours obtained from the two mills were significantly higher than that of DZ-01-99 (13.7) indicating more vivid colors. Rice and wheat flours were paler, with significant $(p<0.05)$ higher $L^{*}$ values than tef flours, which could be because they are refined flours or with very little amount of bran components. Among the tef cultivars effect of mill type was not significant only on DZ-Cr-37 flour color. Such effect of mill type could probably be related to degree of breaking and pulverisation of the bran of the tef grains. However, although significant, the flour color differences attributed to the mill could hardly be detected by eye.

\subsection{Damaged starch}

The damaged starch (DS) determined in tef cultivars varied significantly $(p<0.001)$ with the tef variety and the mill used (Table 2). The mean DS varied with variety in the order DZ-Cr-387 (5.33\%) >DZ-01-99 (4.14\%) = DZ-Cr-37 (4.02\%). Notably higher $(\mathrm{p}<0.01)$ DS was exhibited by mill $2(5.72 \%)$ than mill $1(3.27 \%)$. DS in the tef flours increased with decreasing $\mathrm{D}_{50}(\mathrm{r}=0.6, \mathrm{p}<0.05)$. This agrees with report by Lijuan, Guiying, Guoan, \& Zaigui (2007) stating under the same milling conditions milling to smaller flour particle sizes caused higher DS. Tef variety and mill type interaction effect was also significant $(\mathrm{p}<0.01)$. The level of DS in DZ-Cr-387 flour from mill 1 was much 
higher than the remaining tef cultivars. DS in tef flours from mill 2 were apparently higher than the DS in wheat flour and lower than DS in rice flour evaluated together.

\subsection{Technological functional properties}

Technological functional properties are summarized in Table 3. Cultivar and mill type did not show significant ( $\mathrm{p}>0.05$ ) effect on foaming capacity (FC) and foaming stability (FS) of the tef flours. However, FC values exhibited by the flours from tef cultivars were 1.7 times lower than wheat flours and 1.8 times higher than rice flours. Flour foaming occurs mainly due to a continuous cohesive film formed around the air bubbles in the foam. Similarity in the protein type available in the three tef cultivars and their difference with the reference flours discussed earlier may justify the observed FC's of the flours (Kaushal et al., 2012). The FC score of tef flours could indicate their better suitability than rice in gluten-free food systems that require aeration for textural and leavening properties. The FS of tef flours was much higher than wheat and rice indicating their ability to maintain the foam. Therefore, tef flour could be a better ingredient in gluten-free food system, such as ice-cream, cakes or toppings and confectionary products, which require aeration for textural and leavening properties.

Flour hydration properties were significantly affected by both type of tef cultivar and mill type (Table 3). Among the tef cultivars, DZ-Cr-387 had relatively higher mean water holding capacity (WHC), swelling volume (SV), water absorption index (WAI), water solubility index (WSI) and swelling power (SP) while it scored lower mean water absorption capacity (WAC). The wheat and rice flours had notably lower WHC and SV than tef flours. The higher fiber content in tef flours, as whole meal (Collar and Angioloni, 2014b), could also explain its higher water binding capacity with respect to refined wheat and rice flours (Santos, Rosell, \& Collar, 2008). Tef flours from mill 2 
also had significantly higher WHC, SV, OAC, WAI, WSI and SP. The probable reason for these results could be the smaller flour particle size of flours from mill 2 giving greater surface area for binding water molecules inducing higher water or oil uptake. The significant negative correlation $(\mathrm{p}<0.01, \mathrm{r}=-0.7)$ observed between the $\mathrm{D}_{50}$ of tef flours and their WHC confirms the relationship.

The WAC values of tef flours were apparently higher than wheat flour and lower than the rice flour. WAC has fundamental importance in viscous foods such as soups, sauces, doughs and baked products in which good protein-water interaction is required (Granito Guerra, Torres, \& Guinand., 2004) making tef to be a more suitable ingredient than rice in gluten free formulation. Effect of mill type on OAC of the tef flours was significant $(\mathrm{p}<0.05)$. Flours from mill 1 had lower OAC $(0.83 \mathrm{~g} / \mathrm{g})$ than those from mill $2(0.86 \mathrm{~g} / \mathrm{g})$. The tef flours had apparently similar OAC to the reference flours. Higher OAC in DZCr-387 and DZ-01-99 than DZ-01-37 and in mill 2 than mill 1 can partly be attributed to the lower particle size because oil absorption also depends on the physical entrapment of oil. Flours with high OAC are potentially useful in food products for flavour retention, improvement of palatability and extension of shelf life, mainly in bakery and meat products. High $\mathrm{OAC}$ makes the flour suitable in facilitating enhancement in mouthfeel when used in food preparations. Therefore, products from DZ-Cr-387 and DZ-01-99 may better have these quality attributes than DZ-01-37.

The water absorption index (WAI) measures the volume occupied by the gelatinized starch and denatured protein and other components after swelling in excess water maintaining the integrity of starch in aqueous dispersion (Marson \& Hoseney, 1986).

328 Compared to wheat and rice flours, the mean values of the WAI of the flours from three tef varieties were apparently lower. WSI of the three tef cultivars was apparently higher than that of wheat and especially that of rice flours indicating the presence of higher 
soluble matter content in the tef flours. Tef flours from mill 1 had significantly $(p<0.01)$ lower WAI, WSI and SP $(5.71 \mathrm{~g} / \mathrm{g}, 5.21 \mathrm{~g} / 100 \mathrm{~g}$ and $6.02 \mathrm{~g} / \mathrm{g}$ respectively) than from mill $2(6.20 \mathrm{~g} / \mathrm{g}, 5.83 \mathrm{~g} / 100 \mathrm{~g}$ and $6.58 \mathrm{~g} / \mathrm{g}$ respectively). The value of WSI positively correlated with DS $(r=0.63, \mathrm{p}<0.05)$ because damaged granules hydrate readily and are susceptible to amylolytic hydrolysis. Similarly the effect of flour mean particle size was important $(\mathrm{p}<0.05$ and $\mathrm{r}=-0.5$ to -0.6$)$ on gel hydration properties of the tef flours and this could be due to higher surface area being exposed for water binding. Earlier work by Yetneberk et al. (2005) shows that in sorghum and tef composite flours the WSI increased progressively with increasing proportion of tef, giving injera better quality. The increase in WSI agreed with the observation that, during mixing, compared with sorghum, tef dough tended to be stickier and water-soluble components in the tef flour could have modified the dough rheology and the texture of injera positively (Yetneberk, et al., 2005). In evaluating injera making potentials of sorghum varieties higher WSI gave more fluffy, soft and rollable injera (Yetneberk, 2004). In addition, in flat breads superior quality is associated with wheat flours with high damaged starch content and water absorption (Qarooni, Posner, \& Ponte, 1993). Therefore, based on WSI, starch damage level and water absorption injera from DZ-Cr-387 could be more fluffy, soft and rollable followed by DZ-01-99 and then DZ-Cr-37. At the same time mill 2 seems more suitable for preparation of tef flours for injera.

\subsection{Pasting properties}

Among the tef flours the pasting viscosity (PV) of DZ-Cr-387 (1647mPa.s) was 20\% higher than the equivalent PV of DZ-01-99 and DZ-Cr-37 (Table 4). Trough viscosity (TV) was similar for the three tef varieties, with an average value of $830 \mathrm{mPa}$.s. The mill type influenced the TV of the tef flours in which mill 1 led to the higher value, 862 mPa.s versus $799 \mathrm{mPa}$.s of mill 2. The breakdown viscosity (BV) of DZ-Cr-387 (794 
mPa.s) was about $60 \%$ higher than that of the other two varieties. This means that this white tef variety showed the highest disintegration degree of the swollen systems and alignment of amylose and other linear components in the direction of shear. Mill 2 led to flours with a mean BV value $16 \%$ higher than mill 1 . Consequently, flour from mill 1 had higher thermostability and lower shear thinning and disintegration of swollen systems than from mill 2. The BV of wheat flour was similar to that of tef; however, the rice flour BV was 3.5-5 times higher. Hence, the result obtained supports the suggestion by Bultosa (2007) indicating the potential of tef to be used under high shear conditions. Final viscosity (FV) shows the ability of the material to form a viscous paste and it is mainly determined by the retrogradation of soluble amylose in the process of cooling and tef cultivar type did not influence it. However, the effect of mill type was significant where flours from Mill 1 had FV 10\% higher than mill 2. Setback viscosity (SV) shows how the viscosity of the paste of the flour suspensions recovered during the cooling period. The average SV of DZ-Cr-37 flour was $18 \%$ and $10 \%$ higher than that of flours from DZ-01-99 and DZ-Cr-387 respectively. The mill used also affected significantly the SV of the flours and mill 1 led to flours with SV values $10 \%$ higher than mill 2 . The remarkably lower SV of the tef flours with respect to wheat and rice flours is related to amylose retrogradation and confirm that tef flours retrograde to less extent than other cereals. Such lower reterogradation tendency in the tef flours could make them to be advantageous in formulation of different food products.

The peak time (Pt) and pasting temperature (PT) were also dependent on tef variety. Tef flour from DZ-Cr-37 showed the highest Pt $(8.62 \mathrm{~min})$ and PT $\left(83.1^{\circ} \mathrm{C}\right)$ and the results lie in the range reported by Bultosa (2007). The Pt of the tef flours were lower than both wheat and rice flours. Mean Pt and PT of tef flours from mill $1\left(8.58 \mathrm{~min}\right.$ and $\left.77{ }^{\circ} \mathrm{C}\right)$ were also significantly higher than that of mill $2\left(8.44\right.$ min and $\left.75^{\circ} \mathrm{C}\right)$. 
Significant correlations $(\mathrm{p}<0.05)$ were obtained between the mean particle size of tef

382 flours and its pasting properties, mainly FV, SV, Pt and PT (in all cases $r>0.6$ ). A similar trend was reported for PT and FV of rice flours by Hasjim, Li, \& Dhital (2013). Tef flours with higher WAI, WSI and SP tend to have higher PV and BV $(p<0.05, r \geq 0.6)$ and lower FV, SV, PT and Pt $(\mathrm{p}<0.05, \mathrm{r} \geq-0.6)$.

\subsection{Scanning electron microscopy (SEM)}

Like the other cereal species, tef starch is organized to form starch compound granules of the endosperm (Figure 2). The polygonal shaped starch is clearly seen packed together and protein seems to attach outside of the compound starch granule. In both mill types some of these compound granules were pulverized and individual starch granules are released. However, in mill 2 the starch granule pulverization was more pronounced. Hence, compared to the tef flours from mill 1, tef flours from mill 2 had smaller particle size and closer size distribution and this corroborates the results discussed earlier. In addition both large lenticular starch granules (A-granules) and smaller spherical granules (B-granules) can be observed in wheat. Rice flour particles were the larger having very small polyhedral starch granules.

\subsection{Starch fractions and in vitro starch digestibility}

The three tef varieties had similar contents of free sugar glucose (FGS), starch fractions (RDS, SDS and RS), rapidly available glucose (RAG) and starch digestion rate index (SDRI) (Table 5). However, the effect of mill type on starch vulnerability to the attack of digestive enzymes was significant: mill 2 led to higher RAG, RDS, and RS and lower SDS. As TS was not dependent on milling SDRI was also higher in flours from mill 2. Li, Dhital, \& Hasjim (2014) indicate that damaged starch granules in flour (level 6 structure) have greater enzyme digestibility than intact native starch granules and starch digestibility of flours from milled cereal grains increases with the decreasing flour size. 
406 Tef flours from mill 2 have the lower mean particle size and higher starch damage

407 (Table 2). The damaged starch content had a significant positive correlation with SDRI

408

409

410 and RAG ( $<<0.01, r=0.6$ in both cases). Apparently higher SDRI in the two white tef cultivars (DZ-Cr-37 and DZ-Cr-387) flours from mill 2 than in wheat flour could also be attributed to the higher damaged starch available in them. The lower RDS content in tef flour versus rice makes this cereal particularly interesting for celiac patients that frequently suffer diabetes of type I besides the celiac disease. However it is necessary to demonstrate the same behavior in final products to establish this conclusion as definitive. The FSG content of the three tef cultivar flours (1.5\% dry basis) was more than three and seven times higher than those of wheat and rice flours respectively. Higher FSG available in tef could probably be the reason why cooked tef grain tends to have sweet taste.

\section{Conclusions}

The protein profiles of the three tef cultivars were similar, but different from wheat and rice analyzed as reference. Tef cultivar and mill type used exhibited important effect on flour granulation and uniformity of particle size, starch damage and densities. These parameters were important factors affecting the processing performance of the flours by determining the absorbed water and dissolved flour components and the pasting properties of tef flours. A lighter product could be obtained from DZ-Cr-387 followed by DZ-Cr-37 and then DZ-01-99. This corroborates the report by Fufa, Behute, Simons \& Berhe (2011) stating the higher preference and value of DZ-Cr-387 than DZ-Cr-37 giving brighter or whiter injera which is more preferable to Ethiopian consumers. Western consumers, more accustomed to white and refined cereals, could also prefer this variety. Based on WSI, starch damage level and water absorption results, injera from DZ-Cr-387 could be more fluffy, soft and rollable followed by DZ-01-99 and then 
DZ-Cr-37. At the same time, compared to the Cyclotech Sample mill used in this

432

433

434

435

experiment, the disc mill which is currently being used in Ethiopia for milling tef grain seems more suitable for preparation of tef flours for injera. The results confirm the adequacy of tef flours as ingredients in the formulation of new cereal based foods and the importance of the variety and the mill used on its functional properties. Starch fractions available in the three tef cultivars and indices indicating the in vitro starch digestibility of their flours were equivalent. The effect of damaged starch was more important and tef flours from the disc attrition mill had higher RAG and SDRI. Starch digestibility in the tef flours tended to be lower than the reference flours. Extensively higher FSG in tef may indicate its potential to develop products with different taste.

\section{Acknowledgements}

The research was supported by the Spanish Institutions Ministerio de Economía y Competitividad (Projects AGL2012-35088 and AGL2011-22669), the European Regional Development Fund (FEDER) and Comunidad de Castilla y León (Project VA252A12-2). The authors thank Prof. Belén A. Acevedo and Prof. María Avanza for the help with the SDS-PAGE analysis and Marina Villanueva and Sandra Pérez for the help with in vitro starch digestibility of flours. W. Abebe thanks the Agencia Española de Cooperación Internacional (AECID) grant and Ethiopian Institute of Agriculture for providing the tef cultivars flours.

\section{References}

Abebe, Y., Bogale, A., Hambidge, K.M., Stoecker, B.J., Bailey, K. \& Gibson, R.S. (2007). Phytate, zinc, iron and calcium content of selected raw and prepared foods consumed in rural Sidama, Southern Ethiopia, and implications for bioavailability. Journal of Food Composition and Analysis, 20, 161-168. 
Abebe, W., \& Ronda, F. (2014). Rheological and textural properties of tef [Eragrostis tef (Zucc.)Trotter] grain flour gels. Journal of Cereal Science, 60, 122-130.

Adebowale, A.A., Emmambux, M.N., Beukes, M., \& Taylor, J.R.N. (2011). Fractionation and characterization of teff proteins. Journal of Cereal Science, 54, 380-386.

Akubor, P.I. (2007). Chemical, functional and cookie baking properties of soybean/maize flour blends. Journal of Food Science Technology 44, 619-622.

Al-Rabadi, G. J., Gilbert, R. G., \& Gidley, M. J. (2009). Effect of particle size on kinetics of starch digestion in milled barley and sorghum grains by porcine alphaamylase. Journal of Cereal Science, 50, 198-204.

Alu'datt, M.H., Rababah, T., Ereifej, K., Alli, I., Alrababah, M.A., Almajwal, A.,Masadeh, N., \& Alhamad, M.N.(2012). Effects of barley flour and barley protein isolate on chemical, functional, nutritional and biological properties of Pita bread. Food Hydrocolloids, 26, 135-143.

American Association of Cereal Chemists (AACC). (2000). Approved Methods of Analysis. AACC International. St. Paul, MN, USA.

Beuchat, L.R. (1977). Functional and electrophoretic characteristics of succinylated peanut flour protein. Journal of Agricultural Food Chemistry, 25, 258- 261.

Brown, R.L., \& Richards, J.C. (1970). Principles of powder mechanics. Pergman Press, Oxford.

Bultosa, G. (2007). Physicochemical characteristics of grain and flour in 13 tef [Eragrostis tef (Zucc.) Trotter] grain varieties. Journal of Applied Sciences Research, 3, 2042-2051. 
478 Collar, C., \& Angioloni, A. (2014a). Nutritional and functional performance of high ß479 glucan barley flours in breadmaking: mixed breads vs wheat breads. European Food Research and Technology, 238, 459-469.

481

482

Collar, C., and Angioloni A. (2014b). Pseudocereals and teff in complex breadmaking matrices: impact of lipid dynamics on the bread functional and nutritional profiles. Journal of Cereal Science, 59, 145-154.

Dekking, L.S., Winkelaar, Y.K., \& Koning, F. (2005). The Ethiopian cereal tef in celiac disease. New England Journal of Medicine, 353, 1748-1749.

Deshpande, H. W., \& Poshadri, A. (2011). Physical and sensory characteristics of extruded snacks prepared from Foxtail millet based composite flours. International Food Research Journal, 18, 751-756.

Englyst, K.N., Englyst, H.N., Hudson, G.J., Cole, T.J., \& Cummings, J.H. (1999). Rapidly available glucose in foods: an in vitromeasurement that reflects the glycemic response. American Journal of Clinical Nutrition, 69, 448-454.

Englyst, K.N., Hudson, G.J., \& Englyst, H.N. (2000). Starch analysis in food. In: Meyers RA, editor. Encyclopedia of analytical chemistry. Chichester: John Wiley \& Sons. p 4246-4262.

Englyst, H.N., Kingman, S.M., \& Cummings, J.H. (1992). Classification and measurement of nutritionally important starch fractions. Eurpean Journal of Clinical Nutrition, 46, S33-S50.

FAO/WHO. (2003). Food energy - Methods of analysis and conversion factors. FAO Food and Nutrition. Paper 77, Rome. 
500 Fraser, T.R., Brendon-Bravo, M., \& Holmes, D.C. (1956). Proximate analysis of wheat flour carbohydrates. 1. Methods and scheme of analysis. Journal of the Science of Food and Agriculture, 7, 577-589.

503

Fufa, B., Behute, B., Simons, R., \& Berhe, T. (2011). Strengthening the tef value chain in Ethiopia. Mimeo, Agricultural Transformation Agency (ATA), Addis Ababa.

Granito, M., Guerra, M., Torres, A., \& Guinand, J. (2004). Efecto deprocesamento sobre 506

Hager, A.S., Wolter, A., Jacob, F., Zannini, E., \& Arendt, E.K. (2012). Nutritional properties and ultra-structure of commercial gluten free flours from different botanical sources compared to wheat flours. Journal of Cereal Science, 56, 239247.

Hasjim, J., Li, E., \& Dhital, S. (2013). Milling of rice grains: The roles of starch structures in the solubility and swelling properties of rice flour. Starch/Stärke, 64, , 631- 645 .

Kadan, R. S., Bryant, R. J., \& Miller, J. A. (2008). Effects of milling on functional properties of rice flour. Journal of Food Science, 73, 151-154.

Kaushal, P., Kumar, V., \& Sharma, H.K. (2012). Comparative study of physicochemical, functional, antinutritional and pasting properties of taro (Colocasia esculenta), rice (Oryza sativa) flour, pigeonpea (Cajanus cajan) flour and their blends. LWT - Food Science and Technology, 48, 59-68.

Landillon, V., Cassan, D., Morel, M.-H., \& Cuq, B. (2008). Flowability, cohesive and granulation properties of wheat powders. Journal of Food Engineering 86, 178193. 
Li, E., Dhital, S., \& Hasjim, J. (2014). Effects of grain milling on starch structures and flour/starch properties. Starch/Stärke, 66, 15-27.

Lijuan, S., Guiying, Z., Guoan, Z., \& Zaigui, L. (2007). Effects of different milling methods on flour quality and performance in steamed bread making. Journal of Cereal Science, 45, 18-23.

Marson, W.R., \& Hoseney, R.C. (1986). Factors affecting the viscosity of extrusioncooked wheat starch. Cereal Chemistry, 63, 436-441.

Nelson, A. L. (2001). Properties of high-fibre ingredients. Cereal Foods World, 46, 9397.

Parker, M.L., Umeta, M., \& Faulks, R.M. (1989). The contribution of flour components to the structure of Injera, Ethiopian fermented bread made from tef (Eragrostis tef ). Journal Cereal Science, 10, 93-104.

Qarooni, J., Posner, E. S., \& Ponte, J. G., Jr. (1993). Production of tanoori bread with hard white and other US wheat. Lebensmittel-Wissenschoft und Technologie, 26, 100-106.

Ronda, F., Rivero, P., Caballero, P. A., \& Quilez, J. (2012). High insoluble fibre content increases in vitro starch digestibility in partially baked breads. Journal of Food Science and Nutrition, 63, $971-977$.

Santos, E., Rosell, C.M., \& Collar, C. (2008). Retrogradation kinetics of high fiberwheat flour blends: a calorimetric approach. Cereal Chemistry, 85, 455-463.

Shewry, P.R., \& Tatham, A.S. (1990). The prolamin storage proteins of cereal seeds structure and evolution. Biochemical Journal, 267, 1-12. 
545 Tran, T.T.B., Shelat, K.J., Tang, D., Li, E., Gilbert, R.G., \& Hasjim, J. (2011).

546 Milling of rice grains. The degradation on three structural levels of starch in sice 547 flour can be independently controlled during grinding. Journal of Agricultural and $548 \quad$ Food Chemistry, 59, 3964-3973.

549 Umeta, M., \& Parker, M. (1996). Microscopic studies of the major macro-components 550 of seeds, dough and injera from tef (Eragrostis tef ). SINET Ethiopian Journal of $551 \quad$ Sciences, 19, 141-148.

552 Yetnebrerk, S. (2004). Sorghum injera quality improvement through processing and 553 development of cultivar selection criteria. Ph.D. Thesis Submitted to University of $554 \quad$ Pretoria.

555 Yetneberk, S., Rooney, L.W., Taylor, R.N. (2005). Improving the quality of sorghum 556 injera by decortication and compositing with tef. Journal of the Science of Food sequence tag analysis in tef Eragrostis tef (Zucc.) Trotter). Genome, 49, 365-372.

560

561 
Table 1: Chemical composition of tef flours (\% on dry basis). Wheat and rice flours were included and considered as references

569

\begin{tabular}{|c|c|c|c|c|c|c|c|}
\hline Flour & $\begin{array}{c}\text { Moisture } \\
(\%)\end{array}$ & $\begin{array}{l}\text { Proteins } \\
(\% \mathrm{w} / \mathrm{w})\end{array}$ & $\begin{array}{c}\text { Ash } \\
(\% \mathrm{w} / \mathrm{w})\end{array}$ & $\begin{array}{c}\text { Fat } \\
(\% \mathrm{w} / \mathrm{w})\end{array}$ & $\begin{array}{c}\text { Carbohydrates } \\
\qquad(\% \mathrm{w} / \mathrm{w})\end{array}$ & $\begin{array}{l}\text { Starch } \\
(\% \mathrm{w} / \mathrm{w})\end{array}$ & $\begin{array}{c}\text { Amylose } \\
\text { (\% of starch) }\end{array}$ \\
\hline Tef-brown (DZ-01-99) & $10.5 \pm 0.1 \mathrm{a}$ & $8.9 \pm 0.3 b$ & $2.71 \pm 0.19 \mathrm{c}$ & $2.84 \pm 0.08 \mathrm{~d}$ & $85.6 \pm 0.6 c$ & $75.5 \pm 0.1 \mathrm{c}$ & $21.6 \pm 0.3 \mathrm{a}$ \\
\hline Tef-white (DZ-Cr-37) & $10.3 \pm 0.1 \mathrm{a}$ & $10.5 \pm 0.2 \mathrm{c}$ & $3.52 \pm 0.01 \mathrm{~d}$ & $2.63 \pm 0.06 \mathrm{c}$ & $83.4 \pm 0.2 b$ & $74.0 \pm 0.3 b$ & $21.8 \pm 0.3 \mathrm{a}$ \\
\hline Tef-white (DZ-Cr-387) & $10.4 \pm 0.1 \mathrm{a}$ & $8.9 \pm 0.2 b$ & $2.63 \pm 0.09 c$ & $3.24 \pm 0.06 \mathrm{e}$ & $85.3 \pm 0.3 \mathrm{c}$ & $75.5 \pm 0.4 \mathrm{c}$ & $21.1 \pm 0.4 \mathrm{a}$ \\
\hline Wheat & $12.1 \pm 0.1 b$ & $12.7 \pm 0.2 \mathrm{~d}$ & $0.69 \pm 0.01 \mathrm{a}$ & $1.47 \pm 0.06 \mathrm{a}$ & $85.1 \pm 0.2 \mathrm{c}$ & $78.8 \pm 0.4 d$ & $23.2 \pm 0.5 b$ \\
\hline Rice & $12.2 \pm 0.1 \mathrm{~b}$ & $7.8 \pm 0.3 \mathrm{a}$ & $0.67 \pm 0.01 \mathrm{a}$ & $1.35 \pm 0.04 \mathrm{a}$ & $90.5 \pm 0.3 \mathrm{~d}$ & $87.7 \pm 0.4 \mathrm{e}$ & $21.7 \pm 0.1 \mathrm{a}$ \\
\hline
\end{tabular}

Data are the mean \pm standard deviation. Values with a letter in common in the same column are not significantly different $(\mathrm{p}<0.05)$ 
Table 2. Physical properties of the flours and damaged starch level

574

\begin{tabular}{|c|c|c|c|c|c|c|c|c|c|c|c|}
\hline \multirow[t]{2}{*}{ Variety } & \multirow[t]{2}{*}{ Mill } & \multicolumn{2}{|c|}{ Average particle size } & \multirow{2}{*}{$\begin{array}{c}\text { Bulk } \\
\text { density } \\
\left(\mathrm{g} / \mathrm{cm}^{3}\right)\end{array}$} & \multirow{2}{*}{$\begin{array}{l}\text { True density } \\
\left(\mathrm{g} / \mathrm{cm}^{3}\right)\end{array}$} & \multirow{2}{*}{$\begin{array}{c}\text { Damaged } \\
\text { starch } \\
(\%) \\
\end{array}$} & \multirow[b]{2}{*}{$\mathrm{L}^{*}$} & \multirow[b]{2}{*}{$a^{*}$} & \multirow[b]{2}{*}{$b^{*}$} & \multirow[b]{2}{*}{$\mathrm{h}$} & \multirow[b]{2}{*}{$\mathrm{C}^{*}$} \\
\hline & & $\begin{array}{l}\mathrm{D}_{50} \\
(\mu \mathrm{m})\end{array}$ & $\begin{array}{c}\text { Dispersion } \\
\left(\left(\mathrm{D}_{90}-\mathrm{D}_{10}\right) / \mathrm{D}_{50}\right)\end{array}$ & & & & & & & & \\
\hline DZ-01-99 & 1 & $94.1 \pm 0.8 b$ & $2.51 \pm 0.02 \mathrm{~d}$ & $0.85 \pm 0.01 \mathrm{~b}$ & $1.43 \pm 0.01 \mathrm{ab}$ & $2.48 \pm 0.28 \mathrm{a}$ & $67.1 \pm 0.3 \mathrm{a}$ & $5.08 \pm 0.07 \mathrm{e}$ & $12.1 \pm 0.1 \mathrm{a}$ & $67.3 \pm 0.1 \mathrm{a}$ & $13.1 \pm 0.1 \mathrm{a}$ \\
\hline DZ-01-99 & 2 & $90.7 \pm 0.6 \mathrm{a}$ & $2.17 \pm 0.01 \mathrm{c}$ & $0.79 \pm 0.01 \mathrm{a}$ & $1.42 \pm 0.01 \mathrm{a}$ & $5.56 \pm .14 \mathrm{c}$ & $67.8 \pm 0.1 b$ & $4.83 \pm 0.04 d$ & $13.4 \pm 0.1 \mathrm{~b}$ & $70.1 \pm 0.1 b$ & $14.2 \pm 0.1 \mathrm{~b}$ \\
\hline DZ-Cr-37 & 1 & $98.4 \pm 0.9 \mathrm{~d}$ & $2.58 \pm 0.01 \mathrm{f}$ & $0.87 \pm 0.01 \mathrm{c}$ & $1.47 \pm 0.04 \mathrm{~b}$ & $2.43 \pm 0.16 \mathrm{a}$ & $78.1 \pm 0.1 \mathrm{c}$ & $1.97 \pm 0.02 \mathrm{c}$ & $15.2 \pm 0.2 \mathrm{de}$ & $82.6 \pm 0.1 \mathrm{c}$ & $15.4 \pm 0.2 \mathrm{de}$ \\
\hline DZ-Cr-37 & 2 & $94.7 \pm 0.1 b c$ & $2.14 \pm 0.01 \mathrm{~b}$ & $0.81 \pm 0.01 \mathrm{a}$ & $1.46 \pm 0.01 \mathrm{ab}$ & $5.85 \pm 0.04 \mathrm{c}$ & $78.0 \pm 0.1 \mathrm{c}$ & $1.96 \pm 0.02 \mathrm{c}$ & $14.9 \pm 0.1 \mathrm{~cd}$ & $82.5 \pm 0.1 \mathrm{c}$ & $15.0 \pm 0.1 \mathrm{~cd}$ \\
\hline DZ-Cr-387 & 1 & $95.5 \pm 0.6 \mathrm{c}$ & $2.55 \pm 0.03 \mathrm{e}$ & $0.88 \pm 0.01 \mathrm{c}$ & $1.44 \pm 0.01 \mathrm{ab}$ & $4.91 \pm 0.04 b$ & $83.2 \pm 0.1 \mathrm{e}$ & $1.19 \pm 0.03 \mathrm{a}$ & $14.6 \pm 0.1 \mathrm{c}$ & $85.3 \pm 0.1 \mathrm{~d}$ & $14.6 \pm 0.1 b c$ \\
\hline DZ-Cr-387 & 2 & $94.2 \pm 0.5 b$ & $2.10 \pm 0.01 \mathrm{a}$ & $0.79 \pm 0.01 \mathrm{a}$ & $1.44 \pm 0.01 \mathrm{ab}$ & $5.75 \pm 0.01 \mathrm{c}$ & $81.7 \pm 0.1 \mathrm{~d}$ & $1.31 \pm 0.01 b$ & $15.7 \pm 0.4 \mathrm{e}$ & $85.2 \pm 0.2 \mathrm{~d}$ & $15.4 \pm 0.4 \mathrm{e}$ \\
\hline Wheat & & $56.8 \pm 0.1$ & $1.88 \pm 0.01$ & $0.76 \pm 0.01$ & $1,42 \pm 0.01$ & $5.27 \pm 0.28$ & $94.4 \pm 0.1$ & $0.60 \pm 0.01$ & $9.7 \pm 0.1$ & $86.5 \pm 0.1$ & $9.7 \pm 0.1$ \\
\hline Rice & & $142.7 \pm 0.3$ & $1.70 \pm 0.01$ & $0.84 \pm 0.01$ & $1,43 \pm 0.01$ & $6.51 \pm 0.57$ & $93.9 \pm 0.1$ & $-0.14 \pm 0.01$ & $7.4 \pm 0.1$ & $91.0 \pm 0.1$ & $7.4 \pm 0.1$ \\
\hline Variety & & $* *$ & $* *$ & $* *$ & $*$ & $* *$ & $* *$ & $* *$ & $* *$ & $* *$ & $* *$ \\
\hline Mill & & $* *$ & $* *$ & $* *$ & $\mathrm{~ns}$ & $* *$ & $* *$ & $\mathrm{~ns}$ & $* *$ & $* *$ & $* *$ \\
\hline Variety x Mill & & $*$ & $* *$ & $* *$ & $\mathrm{~ns}$ & $* *$ & $* *$ & $*$ & $*$ & $* *$ & $* *$ \\
\hline
\end{tabular}

575 Data are the mean \pm standard deviation. Values with a letter in common in the same column are not significantly different (p>0.05)

$576 \quad * * *$ and $n$ indicate the level of significance in the effects of tef variety, mill and their interaction. $* \mathrm{p}<0.05, * * \mathrm{p}<0.01$ and ns $=$ not significant $(\mathrm{p}>0.05)$. 
Table 3. Functional characteristics of flours.

\begin{tabular}{|c|c|c|c|c|c|c|c|c|c|c|}
\hline Variety & Mill & $\begin{array}{c}\mathrm{FC} \\
(\mathrm{mL}) \\
\end{array}$ & $\begin{array}{l}\mathrm{FS} \\
(\%)\end{array}$ & $\begin{array}{l}\text { WAC } \\
(\mathrm{g} / \mathrm{g})\end{array}$ & $\begin{array}{l}\text { OAC } \\
(\mathrm{g} / \mathrm{g})\end{array}$ & $\begin{array}{c}\text { WHC } \\
(\mathrm{g} / \mathrm{g})\end{array}$ & $\begin{array}{c}\mathrm{SV} \\
(\mathrm{ml} / \mathrm{g})\end{array}$ & $\begin{array}{r}\text { WAI } \\
(\mathrm{g} / \mathrm{g}) \\
\end{array}$ & $\begin{array}{c}\text { WSI } \\
(\mathrm{g} / 100 \mathrm{~g})\end{array}$ & $\begin{array}{c}\text { SP } \\
(\mathrm{g} / \mathrm{g}) \\
\end{array}$ \\
\hline DZ-01-99 & 1 & $6.5 \pm 2.1 \mathrm{a}$ & $28.8 \pm 12.4$ & $0.89 \pm 0.02 \mathrm{a}$ & $0.83 \pm 0.02 \mathrm{abc}$ & $2.07 \pm 0.12 \mathrm{a}$ & $3.10 \pm 0.03 \mathrm{~cd}$ & $5.57 \pm 0.16 \mathrm{a}$ & $5.37 \pm 0.09 b c$ & $5.89 \pm 0.17 \mathrm{a}$ \\
\hline DZ-01-99 & 2 & $8.0 \pm 0.0 \mathrm{a}$ & $37.5 \pm 17.8$ & $1.06 \pm 0.02 \mathrm{e}$ & $0.87 \pm 0.04 \mathrm{~cd}$ & $2.15 \pm 0.31 \mathrm{a}$ & $3.05 \pm 0.36 \mathrm{~cd}$ & $6.18 \pm 0.25 b c$ & $6.15 \pm 0.41 d$ & $6.58 \pm 0.24 b c$ \\
\hline DZ-Cr-37 & 1 & $7.0 \pm 1.4 \mathrm{a}$ & $43.8 \pm 8.8$ & $1.05 \pm 0.02 \mathrm{de}$ & $0.81 \pm 0.01 \mathrm{a}$ & $2.02 \pm 0.27 \mathrm{a}$ & $2.91 \pm 0.2 \mathrm{c}$ & $5.42 \pm 0.08 \mathrm{a}$ & $4.65 \pm 0.08 \mathrm{a}$ & $5.69 \pm 0.09 a$ \\
\hline DZ-Cr-37 & 2 & $9.0 \pm 2.8 \mathrm{a}$ & $49.4 \pm 31.2$ & $1.02 \pm 0.02 \mathrm{~cd}$ & $0.82 \pm 0.02 \mathrm{ab}$ & $2.31 \pm 0.11 \mathrm{a}$ & $3.19 \pm 0.23 \mathrm{~d}$ & $5.96 \pm 0.27 \mathrm{~b}$ & $4.95 \pm 0.32 \mathrm{ab}$ & $6.27 \pm 0.27 \mathrm{~b}$ \\
\hline DZ-Cr-387 & 1 & $9.5 \pm 2.1 \mathrm{a}$ & $40.3 \pm 31.3$ & $0.96 \pm 0.01 b$ & $0.87 \pm 0.01 \mathrm{bcd}$ & $2.10 \pm 0.16 \mathrm{a}$ & $3.06 \pm 0.01 \mathrm{~cd}$ & $6.13 \pm 0.13 b$ & $5.60 \pm 0.07 \mathrm{c}$ & $6.49 \pm 0.13 b$ \\
\hline DZ-Cr-387 & 2 & $9.5 \pm 0.7 \mathrm{a}$ & $42.2 \pm 3.1$ & $0.99 \pm 0.01 b c$ & $0.89 \pm 0.01 \mathrm{~d}$ & $2.65 \pm 0.07 \mathrm{~b}$ & $3.50 \pm 0.05 \mathrm{e}$ & $6.46 \pm 0.13 c$ & $6.40 \pm 0.32 d$ & $6.70 \pm 0.13 c$ \\
\hline Wheat & & $14.0 \pm 1.4$ & $28.7 \pm 2.9$ & $0.70 \pm 0.01$ & $0.85 \pm 0.01$ & $1.50 \pm 0.12$ & $2.27 \pm 0.11$ & $6.38 \pm 0.09$ & $4.41 \pm 0.07$ & $7.34 \pm 0.07$ \\
\hline Rice & & $4.5 \pm 2.1$ & $0.0 \pm 0.0$ & $1.1 \pm 0.01$ & $0.84 \pm 0.01$ & $1.78 \pm 0.05$ & $2.58 \pm 0.13$ & $7.21 \pm 0.07$ & $1.70 \pm 0.09$ & $6.67 \pm 0.10$ \\
\hline Variety & & $\mathrm{ns}$ & ns & $* *$ & $* *$ & $*$ & ns & $* *$ & $* *$ & $* *$ \\
\hline Mill & & ns & $\mathrm{ns}$ & $* *$ & $*$ & $* *$ & $*$ & $* *$ & $* *$ & $* *$ \\
\hline Variety $\mathrm{X} N$ & Mill & ns & ns & $* *$ & ns & ns & ns & ns & ns & ns \\
\hline
\end{tabular}

\section{Variety X Mill}

ns

standard deviation. Values with a letter in common in the same column are not significantly different $(p>0.05)$

$*, * *$ and $n$ indicate the level of significance in the effects of tef variety, mill and their interaction. $* \mathrm{p}<0.05, * * \mathrm{p}<0.01$ and $\mathrm{ns}=$ not significant $(\mathrm{p}>0.05)$

$\mathrm{FC}=$ foaming capacity, $\mathrm{FS}=$ Foaming stability after $60^{\prime}, \mathrm{WAC}=$ water absorption capacity, OAC $=$ oil absorption capacity, WHC $=$ water holding capacity, $\mathrm{SV}=\mathrm{swelling}$ volume, $\mathrm{WAI}=$ water absorption index, $\mathrm{WSI}=$ water solubility index and $\mathrm{SP}=$ swelling power. 
Table 4. Pasting properties of hydrated flours.

\begin{tabular}{|c|c|c|c|c|c|c|c|c|}
\hline Variety & Mill & $\begin{array}{c}\mathrm{PV} \\
(\mathrm{mPas})\end{array}$ & $\begin{array}{c}\text { TV } \\
\text { (mPas) }\end{array}$ & $\begin{array}{c}\text { BV } \\
\text { (mPas) }\end{array}$ & $\begin{array}{c}\mathrm{FV} \\
(\mathrm{mPas})\end{array}$ & $\begin{array}{c}\mathrm{SV} \\
(\mathrm{mPas})\end{array}$ & $\begin{array}{l}\text { Peak time } \\
(\mathrm{min})\end{array}$ & $\begin{array}{l}\text { PT } \\
\left({ }^{\circ} \mathrm{C}\right)\end{array}$ \\
\hline DZ-99-01 & 1 & $1336 \pm 23 a$ & $858 \pm 73 b$ & $478 \pm 71 \mathrm{a}$ & $1767 \pm 155 \mathrm{a}$ & $908 \pm 83 a b$ & $8.51 \pm 0.10 b$ & $75.2 \pm 0.8 b$ \\
\hline DZ-99-01 & 2 & $1344 \pm 8 \mathrm{a}$ & $829 \pm 72 \mathrm{ab}$ & $515 \pm 70 \mathrm{ab}$ & $1690 \pm 128 \mathrm{a}$ & $861 \pm 56 a$ & $8.47 \pm 0.11 \mathrm{a}$ & $74.9 \pm 1.2 b$ \\
\hline DZ-Cr-37 & 1 & $1304 \pm 37 a$ & $844 \pm 12 b$ & $461 \pm 34 a$ & $1957 \pm 22 b$ & $1113 \pm 23 c$ & $8.73 \pm 0.07 \mathrm{c}$ & $83.1 \pm 0.9 \mathrm{~d}$ \\
\hline DZ-Cr-37 & 2 & $1317 \pm 49 a$ & $744 \pm 44 a$ & $574 \pm 10 b$ & $1713 \pm 46 a$ & $969 \pm 7 b$ & $8.51 \pm 0.03 b$ & $79.4 \pm 1.0 \mathrm{c}$ \\
\hline DZ-Cr-387 & 1 & $1618 \pm 59 b$ & $883 \pm 35 b$ & $735 \pm 24 c$ & $1840 \pm 45 \mathrm{ab}$ & $956 \pm 15 b$ & $8.49 \pm 0.03 b$ & $73.1 \pm 0.6 \mathrm{a}$ \\
\hline DZ-Cr-387 & 2 & $1676 \pm 67 b$ & $823 \pm 43 a b$ & $853 \pm 26 d$ & $1701 \pm 47 \mathrm{a}$ & $878 \pm 17 a$ & $8.33 \pm 0.01 \mathrm{a}$ & $71.8 \pm 0.2 \mathrm{a}$ \\
\hline Wheat & & $2060 \pm 19$ & $1192 \pm 17$ & $868 \pm 6$ & $2512 \pm 30$ & $1319 \pm 13$ & $9.25 \pm 0.04$ & $84.9 \pm 0.3$ \\
\hline Rice & & $4023 \pm 83$ & $1495 \pm 95$ & $2528 \pm 139$ & $3569 \pm 56$ & $2075 \pm 129$ & $9.07 \pm 0.01$ & $75.3 \pm 0.2$ \\
\hline Variety & & $* *$ & ns & $* *$ & ns & $* *$ & $* *$ & $* *$ \\
\hline Mill & & ns & $*$ & $* *$ & $* *$ & $* *$ & $* *$ & $* *$ \\
\hline Variety x Mill & & ns & ns & ns & ns & ns & ns & $*$ \\
\hline
\end{tabular}

Data are the mean \pm standard deviation. Values with a letter in common in the same column are not significantly different ( $>0.05)$

$*, * *$ and ns indicate the level of significance in the effects of tef variety, mill and their interaction. $* \mathrm{p}<0.05, * * \mathrm{p}<0.01$ and ns $=$ not significant $(\mathrm{p}>0.05)$.

$\mathrm{PV}=$ pasting viscosity, $\mathrm{TV}=$ trough viscosity, $\mathrm{BV}=$ breakdown viscosity, $\mathrm{FV}=$ final viscosity, $\mathrm{SV}=$ set back viscosity, and $\mathrm{PT}=$ pasting temperature. 
Table 5. Starch fractions, FSG, RAG and SDRI expressed in \% referred to dry matter

\begin{tabular}{|c|c|c|c|c|c|c|c|c|}
\hline Variety & Mill & $\begin{array}{c}\text { FSG } \\
(\%)\end{array}$ & $\begin{array}{c}\text { RAG } \\
(\%)\end{array}$ & $\begin{array}{c}\text { RDS } \\
(\%)\end{array}$ & $\begin{array}{c}\text { SDS } \\
(\%)\end{array}$ & $\begin{array}{l}\mathrm{RS} \\
(\%)\end{array}$ & $\begin{array}{l}\text { TS } \\
(\%)\end{array}$ & $\begin{array}{c}\text { SDRI } \\
(\%)\end{array}$ \\
\hline DZ-01-99 & 1 & $1.48 \pm 0.08 b$ & $34.3 \pm 0.9 \mathrm{ab}$ & $29.5 \pm 0.8 \mathrm{ab}$ & $38.5 \pm 2.2 b c$ & $7.7 \pm 1.0 \mathrm{bc}$ & $75.7 \pm 1.0 \mathrm{a}$ & $39.0 \pm 1.0 \mathrm{bc}$ \\
\hline DZ-01-99 & 2 & $1.60 \pm 0.06 b$ & $34.8 \pm 0.8 \mathrm{abc}$ & $29.9 \pm 0.7 \mathrm{ab}$ & $36.2 \pm 2.2 \mathrm{abc}$ & $8.0 \pm 1.1 \mathrm{bcd}$ & $74.1 \pm 1.1 \mathrm{a}$ & $40.7 \pm 1.5 \mathrm{bcd}$ \\
\hline DZ-Cr-37 & 1 & $1.18 \pm 0.06 a$ & $34.0 \pm 2.4 \mathrm{ab}$ & $29.5 \pm 2.2 \mathrm{ab}$ & $39.5 \pm 2.5 b c$ & $6.5 \pm 1.1 \mathrm{ab}$ & $75.6 \pm 1.1 \mathrm{a}$ & $39.7 \pm 1.6 \mathrm{ab}$ \\
\hline DZ-Cr-37 & 2 & $1.86 \pm 0.08 \mathrm{c}$ & $38.5 \pm 1.6 c$ & $33.0 \pm 1.5 b$ & $33.0 \pm 2.9 \mathrm{ab}$ & $8.9 \pm 2.3 \mathrm{~cd}$ & $74.9 \pm 2.3 \mathrm{a}$ & $44.4 \pm 1.6 \mathrm{~cd}$ \\
\hline DZ-Cr-387 & 1 & $1.43 \pm 0.01 b$ & $33.8 \pm 2.6 a$ & $29.1 \pm 2.3 \mathrm{a}$ & $40.8 \pm 2.5 c$ & $5.7 \pm 1.6 \mathrm{a}$ & $75.7 \pm 1.6 \mathrm{a}$ & $38.5 \pm 1.6 \mathrm{a}$ \\
\hline DZ-Cr-387 & 2 & $1.49 \pm 0.31 b$ & $38.0 \pm 1.0 \mathrm{bc}$ & $32.9 \pm 0.9 \mathrm{~b}$ & $31.1 \pm 2.2 \mathrm{a}$ & $10.5 \pm 1.5 \mathrm{~d}$ & $74.5 \pm 1.5 \mathrm{a}$ & $44.1 \pm 1.6 \mathrm{~d}$ \\
\hline Wheat & & $0.46 \pm 0.02$ & $39.6 \pm 2.2$ & $35.2 \pm 2.0$ & $44.1 \pm 2.5$ & $2.3 \pm 1.2$ & $79.0 \pm 1.2$ & $41.9 \pm 1.3$ \\
\hline Rice & & $0.20 \pm 0.01$ & $47.4 \pm 1.9$ & $42.4 \pm 1.7$ & $37.4 \pm 2.9$ & $8.2 \pm 2.9$ & $88.0 \pm 2.9$ & $48.3 \pm 1.3$ \\
\hline Variety & & ns & ns & ns & ns & ns & ns & ns \\
\hline Mill & & $* *$ & $*$ & $*$ & $* *$ & $* *$ & ns & $*$ \\
\hline Variety x Mill & & $* *$ & ns & ns & ns & $*$ & ns & ns \\
\hline
\end{tabular}

Data are on dry basis and the mean \pm standard deviation. Values with a letter in common in the same column are not significantly different ( $>0.05$ )

$*, * *$ and $n$ indicate the level of significance in the effects of tef variety. mill and their interaction. $* p<0.05, * * p<0.01$ and ns $=$ not significant $(p>0.05$ ).

$\mathrm{RDS}=$ rapidly digestible starch, SDS = slowly digestible starch, RS = resistant starch, TS = total starch, RAG = rapidly available glucose, and SDRI = starch digestion rate index 